UNIVERSITY
OF DEBRECEN

FACULTY OF

Health

NYÍREGYHÁZA

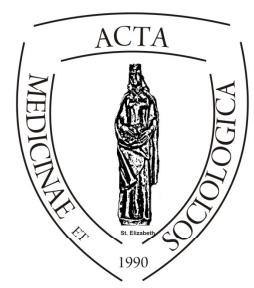

ACTA

MedSoc

VOLUME 7.

2016

\title{
Access to services in rural areas - social issues through an economic prism
}

\author{
Ralitsa Savova \\ Faculty of Economics, University of West Hungary
}

\begin{abstract}
The book Access to Services in Rural Areas: A Comparison of Finland and Hungary is a research, based on the real life situations of citizens and operational environment in Finland and Hungary, focused on the similarities and differences in the context of the two countries, particularly on the areas of Northern Finland and Northern Hungarian Great Plain, and the special features of each of their welfare service systems. One of the main goals of this book is its approach to the topic: the social issues are observed through an economic prism. The authors use this approach to define and analyze the main actors of Local Organization of Social Services (LOSS) - a social care in communal areas. Their model, based on one of the most significant concepts of economics - supply and demand is used in this book to outline the LOSS as a market with providers and clients. The authors of the book proved that LOSS is important for the society because it is responsible for the human being as one of the most significant social and economic factor. They also showed that if LOSS functions adequately, it enables local societies to endure, survive and overcome both internal and external crises, as well that society with high level of education, with low level of anomie and with strong LOSS are more resistant to the crises and can more effectively respond to it. Another goal of the book is its large Appendix.As a closing chapter, which contains more than sixty pages, the Appendix helps the reader to understand better the arguments and the research conclusion of the authors.
\end{abstract}


Key words: social services, rural areas, supply and demand, elderly people, education, anomie

DOI: $10.19055 / \mathrm{ams} .2016 .7 / 22-23 / 9$

\begin{abstract}
Absztrakt: Access to Services in Rural Areas: A Comparison of Finland and Hungary kötet egy nemzetközi összehasonlító kutatás terméke, amely alapján megismerhetjük Finnországban és Magyarországban élők élet helyzetét és a helyi szociális ellátó szervezetek müködését különös tekintettel Észak-Finnország és Észak-Alföld területi sajátosságaira. Az említett könyv egyik fő célja a szociális ügyek megfigyelése egy sajátos gazgazdasági prizmán keresztül. A szerzők látószöge sajátosan határozza meg a helyi szociális ellátó szervezetek (LOSS) érintettjeit a szociális ellátás közösségi tereiben. Az alkalmazott modell egy közgazdasági értelmezési sémára épül - kereslet és kínálat magyarázó keretben, amelyben a szerzők felvázolják a LOSS rendszerét, mint egy kvázi piaci szereplőket: az ellátást szervezők és az ellátottak helyzetét. A könyv szerzői rámutatnak, a helyi szociális ellátó rendszer (LOSS) fontos a társadalom számára mivel ez felel a helyben élők élethelyzetéért, mint egyik legfontosabb társadalmi gazdasági ténye-zőért. Továbbá azt is kimutatták, ha a LOSS megfelelően müködik, akkor lehetséges a helyi társadalmak számára átvészelni a társadalmi válságot. Mivel az erős helyi szociális ellátórendszer ellenállóbb a társadalmi válságra, s jobban képes hatékony választ adni a válság jelenségeire. Például a helyi társadalom egy jó minőségű helyi oktatással esélye-sebb az anómia szintet alacsonyan tartani. A kötetben egy hatvan oldalas Appendix segíti az olvasót a jobb megértésben, amely a fejezetek szerzőinek az érvelését is jól alátámasztja.
\end{abstract}

Kulcsszavak: helyi szociális ellátó rendszer, kereslet kínálat a szociális szolgáltatásokban, idős gondozás, helyi oktatás politika, anomia

LOSS is an abbreviation of Local Organization of Social Services - a collaborative international comparative research cooperation, initiated by professor Rainer Greca (the Catholic University of Ingolstadt, Germany) and professor Thomas R. Lawson (University of Louisville, USA), established in Munich in 1993 by German, American, Hungarian, Finnish, English and Italian research institutes and universities. LOSS is also a term commonly used as a synonym for social care in communal areas. As a term it includes community protection system and "elements of human resource production and preservation on the institutional level, spontaneous social actions to include education, training systems, health promotion, development and implementation of health care systems related to both direct and indirect social support systems", as well production and reproduction of knowledge (Bódi 2014:1).

According to the editors of the book Access to Services in Rural Areas: A Comparison of Finland and Hungary, the aim of this project was to obtain a research-based knowledge about the real life situations of citizens and operational environment and to create a comparative research on well-being of 
the citizens in Finland and in Hungary, particularly focused on the areas of Northern Finland and Northern Hungarian Great Plain. The research plan of the book is focused on the similarities and differences in the context of the countries and the special features of each of their welfare service systems (Editors $3: 2014)$. The book provides the outcomes of the two country regional surveys, but the reader can observe that it is not a strict comparison, because some of the chapters are based on the descriptions of those two regions, not on their comparison. For example, in the chapter: Toward a dynamic theory of Local Organization of Social Services (LOSS) functioning written by Ferenc Bódi, Finland was only mentioned by the author as an example of a country with a courage which could go against historical necessity, same like Hungary after the Treaty of Trianon in 1920.

One of the main goals of this book is its approach to the topic: the social issues are observed through an economic prism. The authors use this approach to define and analyze the main actors of LOSS. Their model is based on one of the most significant concepts of economics - supply and demand. A pillar of the market economy, the supply and demand concept is used in this book to outline the LOSS as a market with providers and clients. The main sectors of the local social services which are separated from each other - public education, health care system and social support system are determined as supply side and the local society - as clients of demand side (Bódi 2014: 5-6). The LOSS model can be symmetrical or dissymmetrical. It is symmetrical when its demand and supply side are balanced and when "the growing social needs are met by a growing capacity of the supply side" (Bódi \& Fekete 2012). The model is dissymmetrical when the social needs do not have an adequate response in supply side, the social services are unsatisfactory or when the social problems like unemployment, for example, are increasing (Bódi 2014: 10).

Even without to be put as a particular aim of this book, the authors achieved an important result - they proved the importance of LOSS for the society. For example, in the chapter Toward a dynamic theory of Local Organization of Social Services (LOSS) functioning, the author Ferenc Bódi convinced the readers that LOSS is important because it is responsible for the human being as one of the most important social and economic factors. He also showed in his chapter that if LOSS functions adequately, it enables local societies to endure, survive and overcome both internal and external crises, as well that society with high level of education, with low level of anomie and with strong LOSS are more resistant to the crises and can more effectively respond to it (Bódi 2014: 12). Furthermore, the countries or regions that have highly developed economy and advanced technological infrastructure are countries that has been investing in human capital (Bódi 2014: 15). There is also an example given in the mentioned chapter about the correlation between the social services, the 
economic development and the demographic boom in the Hungarian Kingdom in the last decade of the 18th century when its population increased to approximately 10 million people. The demolished country in the early 18th century could not be rebuilt later if the educational system in that country was not rebuilt too. As Confucius wrote: "If your plan is for 1 year, plant rice. If your plan is for 10 years, plant trees. If your plan is for 100 years, educate children". The mentioned demographic boom occurred because the establishing at that time of social services like churches and schools had been followed by an economic development that had been followed by a population growth (Bódi 2014: 19). The main sectors of the social services should be not in a contradiction, but should support each other and collaborate successfully. Such prime example, presented very convincingly by Ferenc Bódi in the chapter Toward a dynamic theory of Local Organization of Social Services (LOSS) functioning, shows the importance of education system (the so called supply side) and its correlation with the Catholic church (also supply side). Numerous of church schools were founded at the end of the 18th century in the Hungarian Kingdom. There was also a big variety of branches of the Christian church (Catholic, Calvinist, Lutheran) which were founded there and that time - a consequence of the effect of the Act of Religious Tolerance and Freedom of Conscience ${ }^{1}$ by King John Sigmund (1540-71) at the Diet of Torda (1568). Some of these churches opened their own schools where they recruited many students (it was not necessarily the students to belong to the church) and supported financially the talented ones. The education in the church schools was based on meritocratic approach and was affordable for every social class.

The second example which point out the evolution of LOSS in Hungary is the so called Consolidation Era in 1920s. This period, related with the biggest public investment in education of all time in the country created some of the

\footnotetext{
1 "Our Royal Majesty, as he had decided at the previous debates within his country about matters of religion, confirms as well at the present Diet that every orator shall preach the gospel by his own [personal] conception, at any place if that community is willing to accept him, or if it isn't, no one should force him just because their soul is not satisfied with him; but a community can keep such a preacher whose teachings are delightful. And no one, neither superintendents nor others, may hurt a preacher by this or by the previous constitutions; no on may be blamed because of their religion. No one is allowed to threaten others with prison or divest anyone of their office because of their profession: because faith is God's gift born from hearing and this hearing is conceived by the word of God." "Act of Religious Tolerance and Freedom of Conscience" King John Sigismund (1540 - 71) at the Diet of Torda (1568). John Erdö Transylvanian Unitarian Church (Center for Free Religion, 1990), p 8-9. Translation by Dr. Judit Gellérd. HARVARD SQUARE LIBRARY - a digital library of Unitarian Universalist biographies, history, books, and media.
} 
most significant pages in the history book of the modern public education in Hungary. In the chapter Toward a dynamic theory of Local Organization of Social Services (LOSS) Ferenc Bódi showed the leading role which Kuno von Klebelsberg played for the new school building project after the Trianon Treaty. Among the achievements of Klebelsberg were mentioned the creation of elementary schools in the countryside, the five thousand classrooms which were built in a period of three years in the country (especially in the countryside areas), the new basis for teacher training, the developing of the school network, the modernization of numerous universities - the University of Pécs, the University of Debrecen, the University of Szeged, the complex education system in Hungary from public primary education up to the university level.

While reading this book, the reader can find more and more catching the attention analysis. Such example is about the service access of elderly people in Hungary which is presented in the chapter Characteristic of elderly people's access to social services, written by László Patyán and Gergely Fábián. The authors are focused on questions like how to provide quality services, how to ensure equal and appropriate access having in mind that due to several reasons the elderly people became the most critical target group for the EU's service policy. One of the hot issues which László Patyán and Gergely Fábián put in their focus is the usage of the provision and service of the elderly people, because in Hungary the social benefits can be used only after applying for them. The authors observed that difficulties can appear if an elderly person "has no information about the provisions or eligibility, or if they feel ashamed to apply for assistance or because of disabilities they cannot access them, they will not apply for them and can be left out" (Patyán \& Fábián 2014: 233).

Everything in this chapter is based on data which is proved by the own surveys of the authors, by probe query and questionnaires which they used for the research. Their results show very interesting facts, for example, that in the eastern part of Hungary, which in general is less developed than the western part of the country, the service indicators (the number of services per 100, 000 inhabitants) are better (Patyán \& Fábián 2014: 233). Also according to the settlement size, the services are the best not in the big cities but in towns with about 20,000 inhabitants (Patyán \& Fábián 2014: 233). Among the other interesting conclusions in the current research, based on 985 processed questionnaires, is the fact that the percent of the active and old population is nearly the same in the small towns, in the towns, and in the cities, and also that the elderly people can use public transport usually in an amount that is similar to members of the active age group. The foundation for the current research was based on an earlier settlement level research study (Patyán, 2010) and a probe query prior to this research in 2012 in which was found the following problems 
1. Centralization of the social services: "Services for elderly people even in a municipality with about 100,000 inhabitants is strongly concentrated in the central areas. People who use services live around the service center, while those who live in peripheral areas where the rate of elderly people is higher have less chance to access these services".

2. Immobility of elderly people (demand side) and priority to social services (supply side) at their homes: "Elderly people prefer those services that "go to their homes".

3. Non-consumer behavior of elderly people: "Elderly people think that the social services are basically the duty of the state, meaning they mostly want to use them free or at low prices, compared to other public services for example, health services. These paternalistic attitudes result a low preferences for market services exhibiting non-consumer behavior and a big claim for the state to assume much more responsibility".

4. Gratification of elderly people by those services which they currently use: "Generally they are satisfied with a service if they are able to use it but if they are left out, they will be dissatisfied".

The authors pay attention also to the issue that two third of elderly people (67\%) are put in a disadvantaged situation, due to they live in two or three room households and that is why they cannot get access to a social support. The elderly people also know less about the social services than the active population (Patyán \& Fábián 2014: 236).

In the chapter Anomie as a thermometer of the crisis (experiment) - Social Capacity - phenomenon of the complex crisis, the authors Ferenc Bódi, Jenő Farkas and Zsuzsanna Horváth focus on one of the most painful problem in the individuals and the society, related with the lack of social values - anomie. In their research design they tried to establish a main index assembling independent anomic phenomena observed, which is not the final anomie index, but the social capacity index, which according to the authors needs further elaboration. The etymology of the word "anomie" is related with the Greek word "óvouoc"(anomos), meaning "lawless". As a term, "anomie" was introduced first by the French sociologist Émile Durkheim in 1893. Its meaning is "a condition of instability resulting from a breakdown of standards and values or from a lack of purpose or ideals". ${ }^{2}$ In this chapter the authors did not want neither to provide an additional interpretation of the Durkheim concept of anomie nor to represent the concept in terms of quantitative measures. The purpose of their research was to investigate the concept and to design an experimental index of measurement of

\footnotetext{
${ }^{2}$ https://www.britannica.com/topic/anomie
} 
acute anomie in territorial units of various sizes (Bódi \& Farkas \&Horváth 2014: 149). Showing the historical background of the concept of anomie, the authors also put attention on the contribution of Durkheim to the understanding of how social integration and cohesion influence mortality, and to the study of the relationship between society and health (Bódi \& Farkas \& Horváth 2014: 150). Further on, the Hungarian authors show the Robert Merton's concept of anomie, the distinction that he made between simple and acute anomie, and the various levels of intensity of anomie, and its different types. They also contribute to the concept of anomie with their conclusion: "Wherever societal integration is weak, and social capacity is low, a conglomerate of symptoms of anomie will be found" (Bódi \& Farkas \& Horváth 2014: 157). After going through the historical background of the concept of anomie, the authors tried to create their social capacity index, and when composing it to describe population characteristics like physical and mental health, economic status, well-being and relationship with the world of working, defining the municipal level as the test unit. They examined the social capacity indicators by local municipalities, amounting to 3142 in the territory of Hungary, excluding Budapest. Further on, Bódi, Farkas and Horváth show their results about criminals index, annuitants index, income index, taxpayer index, population change index, abortion index, premature mortality index. The results show for example, that high criminals index municipalities are situated in Southern Transdanubia, low criminal index municipalities are those along the Austrian border, municipalities of the lower quintiles on annuitants index are the regions Western Transdanubia, Central Transdanubia and Central Hungary etc. (Bódi \& Farkas \& Horváth 2014: 161-165).

The book has a large Appendix which was created by Jorma Kurkinen and Jenö Farkas and as well by Ferenc Bódi, Dániel Bódi and Mátyás Bódi. As a closing chapter, which contains more than sixty pages, the Appendix helps the reader to understand better the arguments and the research conclusion of the authors.

\section{References}

1. Bódi, F. (20014) Toward a dynamic theory of Local Organization of Social Services (LOSS) functioning. In. Bódi, F. \& Fábián, G. \& Fónai, M. \& Kurkinen, J. \& Lawson, R. T \& Pietiläinen, H. (2014) Access to Services in Rural Areas: A Comparison of Finland and Hungary. Europäischer Hochschulverlag GmbH \& Co. KG, Bremen, p. 315, ISBN:978-3-86741898-0, pp. 4-26.

2. Bódi, F.\& Farkas, J. \& Horváth, Zs. (2014) Anomie as a thermometer of the crisis (experiment) - Social Capacity - phenomenon of the complex crisis. 
In. Bódi, F. \& Fábián, G. \& Fónai, M. \& Kurkinen, J. \& Lawson, R. T \& Pietiläinen, H. (2014) Access to Services in Rural Areas: A Comparison of Finland and Hungary. Europäischer Hochschulverlag $\mathrm{GmbH} \& \mathrm{Co}$. KG, Bremen, p. 315, ISBN:978-3-86741-898-0, pp. 149-172,

3. Bódi, F. \& Fábián, G. \& Fónai, M. \& Kurkinen, J. \& Lawson, R. T \& Pietiläinen, H. (2014) Access to Services in Rural Areas: A Comparison of Finland and Hungary. Europäischer Hochschulverlag GmbH \& Co. KG, Bremen, p. 315, ISBN: 978-3-86741-898-0

4. Bódi, F. \& Fekete, A. (2012) Changes in supply and demand in elementary education 1988-2009. In (eds) Bódi, F. \& Fábián, G. \& Lawson, R. T. (2012) Local Organization of Social Services in Hungary (Crises Reactions - Changes) Europäischer Hochschulverlag GmbH \& Co. KG, Bremen, pp 268-287.

5. Bódi, F. et al. (2014) Appendix. In. Bódi, F. \& Fábián, G. \& Fónai, M. \& Kurkinen, J. \& Lawson, R. T \& Pietiläinen, H. (2014) Access to Services in Rural Areas: A Comparison of Finland and Hungary. Europäischer Hochschulverlag GmbH \& Co. KG, Bremen, p. 315, ISBN:978-3-86741898-0, pp. 256-315.

6. Durkheim, Emile (1897) [1951] Suicide: a study in sociology. The Free Press.

7. Merton, R. (1968) Social Theory and Social Structure. The Free Press, New York.

8. Patyán, László (2010) Időskorúak Nyírgyházán. Szabolcs-Szatmár-Beregi Szemle Volume 2 pp 237-254

9. Patyán, László \& Fábián, Geregly (2014) Characteristic of elderly people’s access to services In. Bódi, F. \& Fábián, G. \& Fónai, M. \& Kurkinen, J. \& Lawson, R. T \& Pietiläinen, H. (2014) Access to Services in Rural Areas: A Comparison of Finland and Hungary. Europäischer Hochschulverlag GmbH \& Co. KG, Bremen, p. 315, ISBN:978-3-86741-898-0

Savova, Ralitsa, PhD. candidate at Faculty of Economics, University of West Hungary, , Sopron, Hungary; Intern at Institute for Political Science, Centre for Social Sciences, Hungarian Academy of Sciences, Budapest, Hungary, MTA TK PTI, 1250 Budapest, Pf. 20.

ralitsa.savova@tk.mta.hu 